\title{
Twenty-five years of adult adoption in New Zealand 1985-2010 \\ An overview of adult adoption since the implementation of the Adult Adoption Information Act 1985
}

\section{Anne Aburn}

Anne Aburn is the Senior Practitioner (Adoptions \& Caregiver) Wairarapa / Tararua.

\section{Abstract}

When the Adult Adoption Information Act 1985 was introduced it enabled many people who were adopted to reclaim their original identities. The Act also enabled parents who had relinquished children for adoption to reunite with them.

The Act made provision for 24 dedicated social workers known as Adult Adoption Information Officers to be appointed throughout New Zealand. This article, which is a personal reflection on how the Act was implemented and the changes in adoption practice over 25 years, was originally written in 2010 for all Ministry of Social Development Adoption Social Workers.

\section{Early legislation}

During the early years of European settlement in New Zealand informal 'adoptions' were common. These were often arranged within the extended family and legal adoption did not exist until 1881 when a former prime minister, George Waterhouse, gave his support to the Adoption of Children Act 1881 and New Zealand became one of the first countries to formalise adoption. Prior to that children, many of whom were orphans, were fostered on an ad hoc basis. There was no social security at the time and adoption did regularise the position of children, especially older ones, within a family situation. In 1907 the Infant Life Protection Act required that all European births be registered. Registration of Maori births became compulsory in 1913. The Infants Act of 1908, which made provision for the protection of children, did not prevent access to birth records. By 1915 (Births and Deaths Amendment Act) the births of adopted children were re-registered under their adoptive parents' names.

Although some amendments to the Births and Deaths registration closed off access to adoption details, it was not until the Adoption Act was passed in 1955 that a birth parent was able to sign consent to adoption without knowing the identity of the adoptive parents.

\section{0s adoption practice and the clean break theory}

Adoption practice in the 1950s was influenced by the 'complete break theory' - that is, a child placed into an adoptive family should grow up 'as if born to them'. The view was that information should be kept secret from a child and that environment would overcome heredity. 
The NZ Children \& Young Persons Service Adoption Information Manual 1995, page 2 referring to this time states:

From then on a climate of secrecy surrounding the adoption process encouraged a number of erroneous assumptions about the people involved. Birth parents gave their children away because they did not care about them. The less birth parents had to do with the baby, the placement and the adoptive parents, the easier it would be to put the whole experience behind them. If adopted people were happy with their adoptive parents they would not want to know anything about their birth parents. Secrecy was necessary to protect everybody concerned.

\section{Call for openness}

By the 1970s the complete break theory was being challenged: adopted people were expressing their need to have the right to know about themselves, while birth parents who had relinquished children and had never forgotten them, wished to be reunited. Their views were supported by psychological and sociological theory that was developed by people such as Kirk (1964) and Triseliotis (1973).

Adoption support groups were formed by people who were part of the process. These groups provided mutual support and became a base for political action. One group formed Jigsaw in 1976. Jigsaw set up a contact register and helped women find children whom they had placed for adoption. Joss Shawyer, who was a foundation member of Jigsaw, published her book, 'Death by Adoption' in 1979. Shawyer argued that social policies, practices and adoption law forced women to give up their babies.

At the same time there was opposition to making changes to adoption practice and the release of personal information. Some adoptive parents were opposed as they feared the children they had raised would no longer view them as their parents. Some also feared that birth parents who had agreed, when signing consent to adoption, never to search or contact their children, would now interfere in their lives.

The Adoption Support Groups with the support of people such as Keith Griffith, himself an adopted person and Mary Iwanek, an adoptions social worker, all played a prominent role at this time advocating for a more open approach to adoption. This led to the introduction of MP Jonathon Hunt's private member's bill into Parliament in 1977.

As the Prime Minister at the time, Robert Muldoon's attitude was 'live and let live' and the Bill was stalled. The Bill went back to Parliament four times in 1978, 1979 and 1980. It was to be another eight years, and not until there was a change of government in 1984, that the fourth Bill introduced by Fran Wilde, as Hunt was by then a member of Cabinet, became the Adult Adoption Information Act in 1985.

Although it went to a conscience vote, the voting was more or less along party lines. The vote for the Bill was 51 for and 25 against it. Only eight National members supported it while three Labour members voted against it.

The Adult Adoption Information Act was enacted on 13 September 1985. It allowed adopted people aged 20 and over to apply to the Registrar-General of Births, Deaths and 
Marriages for an original birth certificate (pre-adoptive birth certificate). Birth parents wishing to locate an adult adopted child were to apply (Section 8 enquiry) to the Department of Social Welfare in Lower Hutt requesting their child be contacted.

Although part of the Act, enabling planning to begin for its introduction, was to come in to force on 1 March 1986 the main sections did not take effect until 1 September 1986. This allowed time for regulations to be written, a new structure to be organised and for specialist staff to be engaged and trained. It also gave time for those people who did not wish to be contacted to place vetoes on their records.

As previous adoption legislation was under the jurisdiction of the Department of Justice so was this new Act. It was, however, to be implemented by the Department of Social Welfare.

\section{The Adult Adoption Unit}

Because of the specific nature of the new legislation it was decided a separate branch, within the Department of Social Welfare (now Ministry of Social Development) should be set up to implement the new act and that dedicated social workers should be employed.

In the beginning, two offices were established, one in the Department of Social Welfare Head Office and the other in the Lower Hutt District Office. Two social workers in Head Office were to oversee the whole project and the co-ordinating unit was set up at Lower Hutt where they could have easy access to Births, Deaths and Marriages which at that time was located in Levin House in Lower Hutt. The two senior social workers overseeing this new unit, together with clerical support, organised and developed the format that was to be used throughout the country. They were also the adoption information officers for the whole Wellington district.

As it had been decided to appoint dedicated social workers and it was thought the demand would decrease, many social workers were appointed on a temporary basis for two years. The belief at the time was that anyone wishing to make contact with an adopted child or birth parent would do so immediately. It would all be over by then.

Although numbers have declined, people continue to make enquiries.

(I began work in Masterton in April 1986. When my contract ceased in December 1988 I was given a farewell morning tea and presented with flowers. I was back at work in February 1989.)

Social workers and clerical support were selected to cover the whole country. Adult Adoption Information Officers were appointed to Whangarei, Auckland (2), Tauranga, Rotorua, Paeroa, Hamilton, New Plymouth, Gisborne, Napier, Hastings, Palmerston North, Masterton, Lower Hutt (2), Nelson, Blenheim, Greymouth, Christchurch (2), Timaru, Dunedin and Invercargill. Staff hours were allocated according to the size of a district's population e.g. Masterton was given eight hours per week (both social work and clerical). Those in the main cities were employed full time. Although separate, the new staff were supervised by local senior social workers who also oversaw adoption placements. At that time, current adoption placements were arranged and monitored by all Department of Social Welfare social workers according to geographic areas. 
To give wider perspective to the new policy, and for those people who did not wish to engage with a government agency to receive their original birth certificates, there were also provisions within the Act for the appointment of non-official independent counsellors. While some independent counsellors had professional social work or counselling training, many of those appointed had a personal interest and had been involved in Adoption Support Groups and had taken an active role in pushing for changes in legislation. They were paid a fee for each birth certificate issued.

Money was also provided to set up new support groups in each district for adopted people receiving their original birth certificates and for birth parents searching for their adopted adult children. At the time applicants received their certificates they were given details of the local support group. As reunion experiences of the participants were varied, new members appreciated the support of those who had already been through the process. The support groups in the early days helped participants share their experiences and work through their feelings of grief, joy or anger.

\section{Training}

Once the Head Office and Lower Hutt offices were operating, and prospective staff had been interviewed and appointed, training was arranged. The then supervisor of the Student Training Unit in Lower Hutt, (an acknowledged expert in adoption work) was contracted to provide this. Courses were held at Auckland, Porirua and Christchurch in April 1986 for the new social workers and independent counsellors.

During the training the new Act was explained as were the details of procedures to be followed. Topics included forms and recording; birth certificates from Births Deaths and Marriages; Section 8s (birth parent enquiries) from Lower Hutt office; vetoes; issues likely to arise such as grief and anger; publicity material; making selves known; arranging interviews with local radio and newspapers; organising support groups and distributing Birthlink leaflets. These leaflets gave information about the changes that were to take place and how adopted people could apply for original birth certificates. Once new staff had attended a course they then began working in their local offices. Further training seminars were held in 1987, 1988, 1992 and 1995.

\section{Office set up}

In some districts the newly appointed Adult Adoption Information Officers were already on staff. In others, such as Masterton, staff were new to the office and had guidance from a senior social worker who was to be the supervisor. Once space had been allocated adult staff began acquiring their own office equipment. This came from a specific budget. Meanwhile the local staff had already been through all the files and removed the adoption files to separate cabinets.

Once the new staff were settled they began a publicity campaign. They distributed Birthlink leaflets and then began answering enquiries as to how people might apply for an original birth certificate, make a Section 8 (birth parent) application or place a veto.

\section{Procedures}

The procedures for issuing an original birth certificate or making a Section 8 contact were much the same as they are now. 
An adult adopted person sent a written request to Births Deaths and Marriages for an original birth certificate. If there was no veto, Births Deaths and Marriages sent the certificate to the local Department of Social Welfare office where it was recorded with a number, the applicant was notified, usually by letter and an appointment made to collect it. If it had been a local adoption background, information from the adoptive file would be given. Otherwise a request would be sent (by post) to the district where the file was held and a copy of the Report on Child Available for Adoption would be sent back. This form, which had been completed at the time a birth mother decided to place her child for adoption, recorded her personal details. It often included her home address at the time of placement. At the same time applicants were given information on how to search for birth parents.

Section 8 (birthparent) enquires were processed by Lower Hutt Department of Social Welfare who searched for the adopted person. Once the adopted person was located the enquiry was forwarded to the Adult Adoption Information Officer in the district where that person was living. An approach was made and the adopted person would decide whether $\mathrm{s} /$ he wished to have her/his contact details given to the birthparent. Each district kept registers, namely: Register of Birth Certificates Received from Registrar-General; Birth Parent Inquiries, Adoption Information Request for Assistance in Making Contact and Vetoes.

\section{Counselling}

Although the Act specified those receiving original birth certificates would have mandatory counselling before the certificate was issued, views varied. Many adopted people felt, because they were adults, that to be forced to have counselling was a form of discrimination to which they objected. They felt they should not be discriminated in such a way when receiving information about their own identities. Others felt they would like help in coming to terms with issues that might arise as they learnt about their backgrounds and/or coping with reunion. Social workers also saw it as a means of helping clients with searching.

\section{Response to new legislation}

Once all the offices had been set up, the Act came in to force on 1 September 1986. There was a huge demand for original birth certificates for the remainder of that year, with adult adoption staff busy issuing birth certificates and explaining to adoptees how to search for their birth parents.

\section{Original birth certificates}

Adoption statistics have been recorded by both the Department of Social Welfare (Ministry of Social Development) and the Department of Internal Affairs and published in the New Zealand Yearbooks. Wairarapa figures have been taken as a proportionate sample to illustrate a likely general national trend. They also show the age and gender of those who applied for information under the Act.

For the four-month period of 1 September 1986 to 31 December 1986, 3,896 original birth certificates were issued throughout New Zealand. In Wairarapa (Masterton Office) 48 certificates were issued, which is $1.23 \%$ of the total. This is in proportion to the Wairarapa population, which at that time was approximately $1 \%$ of the total New Zealand population.

New Zealand

3,896
Wairarapa

48 
For the 10-year period September 1986 to December 1996, 22,926 original birth certificates were issued. In Wairarapa there were 203, i.e. $0.88 \%$ of the total issued in New Zealand. A further 11,096 were issued in the next 10-year period 1997 to 2006 (Wairarapa 60). Altogether for the 20 years from 1986 to 2006, 34,022 adopted people received their original birth certificates and 9,366 birth parents made a Section 8 application. This is a total of 43,388 people with a personal adoption involvement.

\section{Birth fathers}

As the majority of birth fathers were not included on the birth registration, most adoptees receive an original birth certificate with a blank space for the father's name. In these cases the only way in which adoptees would know who their fathers were was if birth mothers or their families were able and willing to give them their names.

Also when the birth father was not named on the birth registration, he did not have an automatic right to make a Section 8 application. However, if his name was recorded in the departmental records (e.g. on the Report on Child Available for Adoption) or on the birth mother's Section 8 enquiry, an application could be processed. If an agreement between the birth mother and the birth father existed, an application could be made, under Section 15 (3) (b) (1) of the Births, Deaths and Marriages Registration Act 1995, to have his details added to a Pre-Adoptive Record.

\section{Vetoes}

The Act allowed those who did not wish to be identified to place vetoes on their records. It was thought that birth parents had a right to protect themselves especially when the birth had been kept secret from other people. Some adoptive parents believed adopted people should be protected from birth parents coming back into their lives. Although many adoptive parents thought they should have the right to place vetoes, this did not happen. Most of the vetoes were placed between 1 March 1986 and 1 September 1986 for a 10-year period. If vetoes were not renewed they expired after 10 years.

Some 3,825 vetoes were placed by birth parents between 1 March 1986 and 31 December 1996. Of these, 61 were placed by birth fathers. Of the total, 102 were later cancelled and 1,986 had expired by the end of 1996. Adopted people placed 1,303 vetoes and 85 were cancelled with 861 expiring at the end of the 10-year period.

After 10 years many of those who had placed vetoes realised that the fears they had at the time the new legislation was introduced were unfounded and allowed their vetoes to lapse.

\section{Overseas enquiries}

Those people living overseas applied to the Registrar General for their original birth certificates. These were posted directly to them and they were not required to have counselling. Many would then ask for assistance in searching for birth parents. Searching was done by researchers based in the Lower Hutt adoption unit (now Wellington).

Section 8 (birth parent) procedures were the same as for those living in New Zealand i.e. the enquiry was sent to the Department of Social Welfare. The adoptee was then approached by the local social worker and asked if $\mathrm{s} /$ he wished to have contact with the birth parent. 


\section{Not covered by Act}

As the law only provided for adoptees and birth parents, there was no provision for others with an interest in adoption. Adoptive parents were not included and siblings and other family members had no rights. In some instances adoptive parents were apprehensive about their young people making contact with birth family and it is believed some may have placed vetoes when they had no right to do so. At that time a veto could be placed by telephone.

\section{Siblings and birth grandparents}

A number of enquiries came from people who knew their mothers had placed a child for adoption, but their mothers were unwilling to make a Section 8 enquiry. In some instances it was known that siblings were adopted into separate families. Although there was nothing in the new legislation to cover these instances sometimes, if there was sufficient evidence on file that an approach would be welcome, social workers approached the other party to ask if they would be interested in contact and then people were linked up. However, a ruling from the Ombudsman brought this practice to an end. Now siblings and others family members wishing to contact an adopted person are usually advised to make an application to the Family Court under Section 23(3)(b) (iii) of the Adoption Act 1955 quoting 'special grounds.' The applicant writes a letter to the Family Court outlining the reasons why the request is being made. A Judge then decides whether to grant the request or not.

\section{Under 20s}

As the 1985 Act set the age at 20 for the release of identifying information, those under 20 could not make an enquiry without their adoptive parents' knowledge. In many cases it was the parents who made the enquiry. In those cases they could only be given non-identifying information unless there was very clear evidence on the file that contact would be welcomed. In the larger Department of Social Welfare offices there was often a social worker who dealt with all under 20s enquiries.

\section{Other legislation}

Under the Adult Adoption Information Act 1985, an original birth certificate could be made available only to the adopted person. There was no entitlement to it from any other person. This is still the case. For those who may wish to obtain information about a deceased adoptive person they can apply to the Registrar-General of Births, Deaths and Marriages quoting Section 76 of the Births, Deaths and Marriages Registration Act (1995). Under the Act, the Registrar-General has to verify that all immediate parties to the adoption are deceased. To do so, it may be necessary for searches of marriage and death registers to be made. There are financial costs. If the applicant can provide conclusive evidence, by way of death certificates or other documentary evidence, searching fees will not be charged.

Although not directly linked to the Adult Adoption Information Act, the Official Information Act 1982 and the Privacy Act 1993 may influence the way some 'other' enquiries are dealt with. 


\section{Adoption Information and Services Unit}

The Adoption Information and Services Unit was formed in 1990 with Mary Iwanek as manager. This was located in the Head Office of the Department of Social Welfare. All adoption work was brought together. Policy decisions were consistent and regular meetings ensured uniformity of practice. Regular newsletters from Head Office were issued. The Lower Hutt co-ordinating unit moved to Wellington.

Those social workers who had temporary contracts as Adult Adoption Information Officers were given permanent appointments. Although some continued to practise mainly adult work, gradually all became responsible for both adult and placement. A later development saw the growth of intercountry applications and the Adoption (Intercountry) Act was passed in 1997.

In the early years adoption workers had regular meetings and attended a number of Adoption Conferences. These seminars provided an opportunity for staff to discuss how the Act was working; reflect on practice issues, new adoption thinking and to train new staff. It also meant that social workers knew all their colleagues throughout the country and that that personal network ensured a uniformity of practice that remained consistent nationwide.

Since 1998 a number of conferences and seminars have been organised by Adoption Support Groups and ICANZ (Intercountry Adoption of New Zealand). Some adoption social workers based in the town where these were held have attended. Others have attended at their own expense.

\section{Recent research}

Jill Kennard in her thesis 'Adoption Information: The Repossession of Identity' (1991) surveyed a sample group of 145 who had received their original birth certificates between 1986 and 1990. Jill concluded that generally the Adult Adoption Information Act was working well for adopted people.

In her summary she says the information gathered helped to dispel a number of the prevalent myths about adoption and adopted people:

- A large majority had wanted to know more about their origins for some time. The introduction of the Act did not trigger their interest.

- Adopted people of all ages wanted to know more about their origins. Wanting to know is not something that increases or lessens with age.

- For most people, finding out more was not enough, they needed to meet and get to know birth relatives.

- Adopted people who made the initial contact themselves got more positive results than mediators. Adopted people are very capable of making successful contact and do not need mediators to do it for them.

- Many adopted people did not tell their adoptive parents they were searching or meeting birth relatives as, although they were clear that they had the right to search, they did not want to hurt or upset them. This is not underhand behaviour or a symptom of a poor adoptive relationship; it is more likely a sign of the adoptive parents' anxiety and fear. 
- There was little change in existing relationships between adopted people and their adoptive parents. Meeting birth relatives does not threaten the adoptive relationship, which is most likely to remain the same.

- A significant number of adoptive parents have been in contact with their adopted son or daughter's birth relatives, and many have established ongoing relationships. Adoptive and birth parents do not have to be in a conflict situation. It is instead a unique opportunity for both.

- Adopted people can successfully integrate two or more families into their lives. Finding their birth relatives does not mean they relinquish their adoptive ones.

- Only one person regretted searching. Regardless of what they learn, almost all adopted people do not regret searching.

- The willingness of adopted people to see the birth parents' right to privacy as being more important than their own right to information, as well as their unwillingness to hurt their adoptive parents was apparent. This shows that adopted people are not selfish and inconsiderate.

In June 1997 Mary Iwanek presented a paper at the International Conference on Adoption and Healing organised by the New Zealand Adoption Education and Healing Trust. She reviewed past adoption practices and social standards and related them to present-day attitudes. She concluded that the Adult Adoption Information Act had been 'overwhelmingly successful in providing for those who wish to have identifying information about each other. Search and reunion may not always have a happy ending, but is still worth pursuing. It has also identified that for those who are not included in the Act, information is difficult to obtain.'

Griffiths (1998) in New Zealand Adoption: 1840-1996 (pp. 575-586) includes an extensive list of articles and papers on adoption written prior to 1996.

\section{Reviews}

Over the years there have been moves to have all the adoption legislation reviewed and updated. Unfortunately it does not seem to be a matter of national importance for Parliament to consider in depth. Except for some amendments there have been no major changes to the 1955 Adoption Act.

In 1979 Patricia Webb of the Justice Department reviewed the law on adoption. This was followed in 1987 by a paper on Proposals for Discussion of the 1955 Adoption Act produced by an Interdepartmental Working Party set up by the Department of Justice.

More recently, in 1999 the Law Commission prepared a preliminary paper titled 'Adoption Options for Reform' to consider all aspects of adoption. The Commission's conclusions were published as 'Adoption and its Alternatives' in September 2000. The report made many recommendations for changes in adoption law and practice.

In respect of adult adoption the Commission's main recommendations were:

- Adoption records (including court records and Department of Social Welfare records) be open to inspection as of right by adoptees, adoptive parents and natural parents. 
- That after a three-year period no new vetoes to be placed (although existing vetoes can be renewed at 10-year intervals until the death of the veto placer)

- There be no mandatory counselling.

Although the paper went before a parliamentary select committee there was a stalemate and no further action occurred.

Lianne Dalziel in a speech to Parliament on 17 July 2003 titled 'Changes to Family Law Legislation in the 21st Century' put forward a very persuasive argument for the need for adoption reform. The Care of Children Act 2004 was passed, but there still have been no major changes to adoption legislation.

\section{Recent developments}

With a drop in funding, national meetings are no longer held and very few adoption social workers attend conferences organised by voluntary adoption groups. The departmental structure has changed again and now adoption work is back with the regions and the dedicated national office section incorporated into the general care and protection structure.

The level of adult adoption work has diminished and is only a minimal part of an adoption social worker's role. Wellington office does continue to coordinate a number of enquiries from adopted people and birth parents living overseas.

Now as well as education and preparation sessions, social workers spend considerable time writing placement assessments. A more recent development has been the growth in intercountry adoption applications. This involves writing home studies and then collating all the documents required by the various sending countries.

More changes are coming as new policy is introduced. Adoption social workers and caregivers' social workers will work together to achieve permanency for children currently in care. (Note: The Home for Life programme was launched by the Minister for Social Development, Paula Bennett, on 11 August 2010. Parenting Orders are made under the Care of Children Act 2004)

\section{The future}

In 2006 only 679 original birth certificates were issued and 145 Section 8 applications made.

With changes in adoption practice and the emphasis on open adoption the demand for original birth certificates, by those adopted since 1986, will be minimal - except for those who wish to have the actual certificate. Few will need assistance in searching.

However, as the number of children being adopted from overseas increases there could be a greater demand by them for information about their family backgrounds. It is acknowledged that in many instances the information is not available but maybe some form of international cooperation (perhaps under The Hague Convention) might make it possible for some of these adopted people to learn their identities. A more recent development is the increased interest in surrogacy as such arrangements have to be finalised by adoption. This could also lead to identity issues in the future. 


\section{Conclusion}

With a total of 43,388 New Zealanders with a personal adoption involvement (1986 to 2006 - NZ Year Book 2008) receiving information, this means that not only they, but also their families - children, grandchildren - have been able to reclaim their biological identities. Many adoptees and birth parents were reunited and many formed on-going relationships. Most have found the search and reunion a positive experience. And as Jill Kennard says this has helped to dispel a number of prevalent myths about adoption and adopted people.

Now after 25 years, and despite some limitations such as siblings not having an automatic right to have information, and to be able to search for a family member, the whole adult adoption programme may be considered a success. Mary Iwanek's conclusions that the Act has been successful may be endorsed and recognition should be given to her for her foresight and the pro-active way in which she worked to make the programme a success.

\section{References}

Department of Justice. (1987). Adoption Act 1955: A review by an interdepartmental working party: Proposals for discussion. Wellington: Department of Justice.

Dalziel, L. (2003). Changes to family law legislation in the 21st century. July 17 Beehive. Retrieved from http: / / www. beehive.govt.nz/node/17342.

Dominick, C. (1988). Early contact in adoption. Wellington: Department of Social Welfare.

Griffiths, K. (1998). New Zealand adoption: History and practice-social and legal - 1840-1996. (Wellington) 132.

Iwanek, M. (1997). Healing history: The story of adoption in New Zealand. Social Work Now, 8, 13-17.

Kennard, J. (1991). Adoption information: The repossession of identity. Unpublished MA thesis. Wellington: Victoria University.

Kirk, H.D. (1964). Shared fate: A theory of adoption and mental health. New York: Free Press of Glencoe, a division of Macmillan.

Law Commission. (2000). Report 65. Adoption and its alternatives. A different approach and a new framework. Wellington: New Zealand.

New Zealand Child \&Young Persons Service. (1995). Adoption information manual (p. 2).

New Zealand Year Book. (2008).

Shawyer, J. (1979). Death by adoption. Cicada Press.

Triseliotis, J. (1973). In search of origins. Routledge and Keegan Paul.

Weaver, A. (1999). Addressing the psycho-social implications in social policy: The case of adoption and early intervention strategies (pp. 53-61). MPP Research Paper, Victoria University of Wellington.

Webb, P. (1979). A review of the law on adoption. Wellington: Department of Justice.

\section{Legislation}

1881 Adoption of Children Act

1907 Infant Life Protection Act

1908 Infants Act

1915 Births and Deaths Registration Amendment Act

1955 Adoption Act

1982 Official Information Act

1985 Adult Adoption Information Act

1993 Privacy Act

1995 Births, Deaths and Marriages Registration Act

1997 Adoption (Intercountry) Act

2004 Care of Children Act 